\author{
St ud i P hilos o p h i c a \\ Wrat i s l a vi e n s i a \\ vol. XVI, fasc. 2 (2021)
}

https://doi.org/10.19195/1895-8001.16.2.11

\author{
JAN KRASICKI \\ ORCID: 0000-0003-2700-7715 \\ Uniwersytet Wrocławski
}

\title{
Postrenesans rosyjski
}

Łukasz Leonkiewicz, Postrenesans rosyjski. Kierunki i perspektywy rozwoju wspótczesnej filozofii rosyjskiej na przykładzie koncepcji W. Bibichina i S. Chorużyja, Wydawnictwo Naukowe Scholar, Warszawa 2019, ss. 316.

Badania nad rosyjską myślą religijną w Polsce mają już swoją ugruntowana i wieloletnią tradycję. Tradycja inspiruje, ale i ogranicza. Dotychczasowe opracowania ograniczały się do myśli tak zwanego Srebrnego Wieku, a obszar wykraczajaccy poza ten okres jak dotąd stanowił swoistą terra incognita. Poza sfera zainteresowań badaczy pozostawała tym samym cała gama unikalnych zjawisk, takich jak choćby fenomen powstałej w kręach rosyjskiej emigracyjnej teologii prawosławnej — tak zwanej syntezy neopatrystycznej. Zadaniu przezwyciężenia tego badawczego impasu wychodzi naprzeciw książka Łukasza Leonkiewicza. W swej propozycji badawczej warszawski badacz nie tylko poszerza zakres badań, lecz oferuje nowe podejście badawcze. Cechuje się ono przede wszystkim rewizją w stosunku do utrwalonego i — wedle określenia uczonego — „wypaczającego" obraz tej tradycji modelu odczytywania religijnej tradycji myślowej Rosji przez pryzmat rosyjskiego renesansu religijno-filozoficznego. Próbę przezwyciężenia tej ograniczającej perspektywy badawczej podjął warszawski uczony na przykładzie dwóch wybitnych współczesnych przedstawicieli formacji określonej mianem „postrenesansu” Włodzimierza Bibichina i Sergiusza Chorużyja.

Książka Leonkiewicza składa się z trzech części. Potraktowane osobno mogły się wydawać osobnymi rozprawami, a budowa książki niespójna. Tak jednak nie jest i chociaż w jej strukturze głównemu problemowi poświęcona jest trzecia część rozprawy Postrenesans rosyjski, dwie poprzedzające części - Ciagłość tradycji. Tradycja bizantyjska $w$ myśli rosyjskiej oraz Między a neopalamizmem a palamizmem - stanowią niezbędną podbudowę historyczną, teologiczną oraz filozoficzną. 
Leonkiewiczowi zdaje się chodzić bowiem nie tylko o immanentną analizę poglądów wymienionych dwóch reprezentatywnych myślicieli rosyjskiego „postrenesansu", lecz o problem znacznie istotniejszy, czyli pytanie o tożsamość i ciągłość myśli rosyjskiej XIX-XXI wieku. Na czym się ona buduje? Co ją funduje i określa? Czy wyraża się ona w wierności tradycji bizantyjskiej, neoplatońskiej, arystotelesowskiej itp., czy może w czym innym? A wreszcie jakie są perspektywy rozwoju myśli rosyjskiej doby najnowszej?

W części pierwszej pracy badacz stawia pytanie o obecność tradycji bizantyjskiej w myśli rosyjskiej ukazując tę kwestię w całej jej złożoności, czyli zawiłych „dróg teologii rosyjskiej teologii" (J. Florowski), specyfiki myśli rosyjskiej, odrębności dziejowego doświadczenia Rosji itp. Opinie w tej kwestii cechuje duża rozbieżność, zwłaszcza jeśli wziąć pod uwagę z jednej strony oceny badaczy reprezentujących własne swobodne stanowisko badawcze, a z drugiej przedstawicieli opcji konfesyjno-prawosławnej. Dlatego w tej części pracy uczony, ukazując istniejące sprzeczności i aporie, dokonuje jednocześnie wstępnych, acz niezbędnych uporządkowań terminologicznych, systematyzacyjnych oraz metodologicznych, przedstawiajac cały wachlarz kontrowersji i problemów (na przykład problem „prawosławności”), z których każdy wydaje się tak istotny i ważny, że mógłby stanowić przedmiot odrębnych analiz. Na szczęście warszawski filozof i teolog prawosławny potrafi z nich wydobyć elementy najistotniejsze dla problemu badawczego i na nich się skupia.

Spośród wielu innych zagadnień uczony pokazuje między innymi to, jak dalece błędna i do jak fałszywych konkluzji może prowadzić utrwalona w literaturze przedmiotu stereotypowa identyfikacja myśli prawosławnej z osiągnięciami rosyjskiej filozofii religijnej, zwłaszcza Srebrnego Wieku. Ważne przy tym wydaje się i to, że w prowadzonych analizach badacz nie unika zajęcia własnego stanowiska. Przeciwnie, dopuszczając do głosu różne strony, eksponuje je wyraźnie, przy czym nie upraszcza podejmowanych zagadnień, lecz ukazuje je w całej ich złożoności oraz wielostronności. To duża wartość tej książki, która przekłada się na jej obiektywizm oraz krytycyzm. Stąd, kiedy Leonkiewicz podejmuje na przykład spór o ,prawosławność" rosyjskiej filozofii religijnej, głównie w odniesieniu do jej neopatrystycznej reinterpretacji stojącej pod znakiem dzieła o. J. Florowskiego, postępuje konsekwentnie jak badacz, a nie rzecznik prawosławnej ortodoksji.

Uczony podkreśla przy tym, że w istniejących opracowaniach dotyczących filozofii rosyjskiej jako całości powtarzają się dwa poglądy dotyczące jej źródeł i inspiracji. Pierwszy głosi patrystyczny charakter myśli rosyjskiej i upatruje jej zakorzenienia w patrystyce greckiej. Drugi, w odróżnieniu od pierwszego, niechętny „orientalizowaniu” myśli rosyjskiej, stara się natomiast wykazać jej filozoficzność a zarazem i jej zachodnioeuropejskość. W tym kontekście badacz wydaje się bronić tezy o pozytywnym znaczeniu filozofii religijnej ożywiającej skostniałą „teologię katechizmową", co zakłada dynamiczne pojęcie prawosławia, jako „prawosławia poszukujących" (W. Hryniewicz), a nie tylko prawosławia dogmatyków.

Pytając o obecność tradycji bizantyjskiej w rosyjskiej myśli religijnej oraz teologii prawosławnej XX wieku, warszawski uczony zwraca uwagę na fakt, że analiza treści doświadczenia religijnego prawosławia rozpoczęła się już w Srebrnym Wieku, jednak z powodu wielu przyczyn, z których najważniejszą była chyba słaba 
znajomość tradycji bizantyjskiej, trudno odnaleźć prostą kontynuację tego sposobu myślenia $\mathrm{w}$ dziełach myślicieli tej formacji. Jako pozytywne przykłady tej sytuacji wskazuje na postaci takie jak P. Floreński, S. Bułgakow czy L. Karsawin, których dzieła są uznawane za kontynuację myśli patrystycznej, podkreślając jednocześnie, że trudno uznać za takie prace W. Sołowjowa, braci S. i J. Trubieckich czy M. Bierdiajewa. Szukając związków między tradycją patrystyczną oraz rosyjską myślą religijną, badacz udanie eksponuje tak ideową ciągłość jak jej zerwanie, a nawet przeinaczanie, nadinterpretacje, dowolności, w końcu, utratę więzi pomiędzy nimi. Mianowicie ukazując na przykład związek idei „pośrednictwa” w rosyjskiej myśli religijnej oraz $\mathrm{w}$ tradycji bizantyjskiego hezychazmu, zauważa, że odpowiedź myślicieli rosyjskiego renesansu filozoficzno-religijnego nie miała już bizantyjskiego charakteru, albowiem Sofia Sołowjowa, Floreńskiego czy Bułgakowa to „nie energie, to coś więcej. Jako pośrednik jest już nie działaniem Absolutu, lecz bytem pośredniczącym, dającym istnienie, ku sobie pociągającym, przemieniającym i jednoczącym z Absolutem" (s. 29).

W drugiej części książki Między a neopalamizmem a palamizmem zostało postawione pytanie o stosunek myśli chrześcijańskiej do dziedzictwa neoplatońskiego, a w wymiarze ściślejszym o stosunek ortodoksyjnej teologii bizantyjskiej, w tym, głównie palamizmu do neoplatonizmu. Problem tej części rozważań został ujęty w dwu aspektach — historycznym oraz systematycznym, samo zaś ścieranie się neoplatonizmu z chrześcijańskim Objawieniem, które datuje się od II wieku, ukazane zostało jako przebiegająca przez całe dzieje cywilizacji wschodniochrześcijańskiej walka dwu paradygmatów, z których tylko jeden ma rację bytu, a szansa ich syntezy wydaje się raczej wątpliwa. Jako odpowiedź na tę sytuację w XX wieku, jak trafnie się zauważa, pojawiła się neopatrystyka, która była chrześcijańską reakcją na neoplatonizm rosyjskiej filozofii religijnej, co wydaje się zarazem potwierdzać pogląd, że „nieprzystawalność myślenia neoplatońskiego i wschodniochrześcijańskiego”, choć poznawczo nadal ważna, „pozostaje nie do końca uświadomiona” (s. 84).

W dalszym toku analiz badacz, powołując się między innymi na pisma wybitnego znawcy neoplatonizmu A. Łosiewa (który sam był neoplatonikiem), trafnie podkreśla, że wielki błąd popełniają ci, którzy uważają, iż historycznie neoplatonizm był poprzednikiem czy nawet źródłem chrześcijaństwa. Przeciwnie, dla wschodniego chrześcijaństwa, dla którego nie było innego sposobu, aby wyrazić swoje prawdy w sposób inny niż w kategoriach neoplatońskich, neoplatonizm, wbrew powierzchownym opiniom, nie był sojusznikiem, lecz śmiertelnym wrogiem, a tacy neoplatonicy jak Porfiriusz, Jamblich czy Julian Apostata byli autorami „najzłośliwszych traktatów przeciwko chrześcijaństwu”. Przedstawicielem neoplatonizmu, na którego przykładzie badacz szczególnie udanie zilustrował relacje neoplatonizmu i chrześcijaństwa, był Julian Apostata, prawdziwy odnowiciel pogaństwa, w którego osobie „neoplatonizm w ogóle, jako ostatni głos myśli antycznej” jednocześnie wyraził tak ,swój pogardliwy stosunek do chrześcijaństwa”, jak „pragnienie kontynuowania kultury helleńskiej w jej antycznej formie" (s. 92). W tym nurcie problemowym autor rekonstruuje rywalizację kultury antyku i chrześcijaństwa, począwszy od Plotyna i jego następców, przez Juliana Apostatę, Pseudo-Dionizego aż do etapu, jak to określa, ,anatematyzowania filozofii” (s. 98). Odwołując się zaś 
do szerokiego kontekstu źródłowego, począwszy od znanego traktatu Porfiriusza Żywot Plotyna po dzieła Orygenesa, na obszernym materiale źródłowym, badacz wszechstronnie pokazuje, na czym w istocie polega różnica między chrześcijaństwem i neoplatonizmem, broniąc tezy o suwerenności poznania biblijnego wobec poznania filozoficznego.

Osobne miejsce w swych analizach autor poświęca poglądom Pseudo-Dionizego, ujmując je nie w całości jego nauki, lecz w jej związku z neoplatonizmem. Jest to ważne o tyle, że myśl autora Teologii mistycznej stanowi jedną z niewielu w historii Bizancjum prób pogodzenia myśli chrześcijańskiej z tradycją starożytną. Warszawski uczony, wykorzystujac swoją fachową wiedzę teologiczną oraz filozoficzną, umiejętnie oddziela tutaj wątki rdzennie biblijne oraz chrześcijańskie od zakamuflowanych w chrześcijańskiej symbolice, a w istocie obcych chrześcijańskiemu depositum fidei, treści platońskich (neoplatońskich) i w konkluzji stwierdza, że nie tylko w swym platońskim dualizmie, nauce o materii etc., ale przede wszystkim w zapoznaniu bogo-człowieczego synergizmu i teandryzmu Pseudo-Dionizy mijał się z chrześcijaństwem. Słuszna jest opinia, że kluczowy temat synergizmu, stanowi zarazem otwarcie nowej tradycji w pojmowaniu relacji Boga, człowieka i świata, polegającej na odejściu od koncepcji „dynamicznej” ufundowanej na źródłowo neoplatońskim (emanatystycznym) pojęciu mocy (dynamis) Pseudo-Dionizego w kierunku koncepcji „energijnej” ( energeia), bazującej na pojęciu energii jako „działania” (s. 95-96), zapoczątkowanej przez Maksyma Wyznawcę, a doprowadzonej do swej teologicznej dojrzałości w XIV wieku przez Grzegorza Palamasa. Rozprawa z neoplatonizmem — jak się zdaje — nie była i nie mogła być w chrześcijaństwie nigdy ostateczna - neoplatonizm był niejako „cieniem” chrześcijaństwa (podobnie jak gnoza), dlatego trafne wydaje się postawione pytanie, czy myślenie neoplatońskie należy „tylko do przeszłości” (s. 98), czy też w tradycji prawosławnej przeżywa ciągłe okresy nawrotu. W swoich analizach badacz udanie wykorzystuje tutaj prace tak znakomitych znawców problemu jak B. Tatakis, J. Meyendorff czy A. Łosiew.

Jako kolejny i ostatni już etap napięć pomiędzy neoplatonizmem a ortodoksją w myśli bizantyjskiej przedstawia uczony czternastowieczny okres sporów hezychastycznych, w których głównym bohaterem po stronie ortodoksów był Grzegorz Palamas, a po stronie neoplatoników Barlaam z Kalabrii i Nicefor Gregoras. Jak dowodzi, o kluczowej roli sporu neoplatonizmu i chrześcijaństwa w tradycji prawosławia świadczy to, że choć okres ów nie przebiegał już pod znakiem ,anatematyzowania" filozofii, lecz pod znakiem chyba najistotniejszego dla tej doby sporu teologicznego dotyczącego praktyki modlitewnej bizantyjskich mnichów doświadczajaccych tak zwanego ,światła Taboru" — napięcie między neoplatonizmem a ortodoksją dochodzi wówczas szczytu.

Uzasadniając tę tezę na gruncie literatury źródłowej oraz sekundarnej (Enneady Plotyna, Triady oraz 150 rozdziałów Palamasa, prace A. Łosiewa), Leonkiewicz bardzo źródłowo i wnikliwie w osobnych podrozdziałach rozdziału drugiego (Plotyn i Palamas) przeanalizował oraz porównał ze sobą zagadnienie Jedna-Absolutu u Plotyna z osobowym trynitarnym Bogiem w nauce Grzegorza Palamasa oraz wiążące się tym zagadnieniem kwestie metafizyczne, kosmologiczne i antropologiczne. W konkluzji prowadzonych rozważań oraz porównawczych analiz 
uczony ukazał, jak dramatyczna $\mathrm{w}$ istocie była $\mathrm{w}$ historii bizantyjskiej teologii walka o żywego Boga Biblii, „Boga Abrahama, Izaaka i Jakuba”, z bezosobowym neoplatońskim Absolutem. W tym kontekście trafna jest konkluzja, że po upadku Bizancjum, dopiero w XIX wieku w Rosji dokonało się ponowne spotkanie tych dwóch tradycji i wznowienie tego ,nowego-starego" sporu.

Temu zagadnieniu został poświęcony również rozdział trzeci - Neoplatonizm Florieńskiego i Bułgakowa a teologia hezychastyczna - drugiej części, w którym badacz wyniki swych dotychczasowych analiz odniósł do dzieł myślicieli rosyjskich epoki Srebrnego Wieku, szczególnie do myśli P. Floreńskiego i S. Bułgakowa. Myśl S. Bułgakowa warszawski uczony rozpatruje przede wszystkim z punktu widzenia dychotomii Sofia czy energie?, trafnie odczytując jego sofiologię (praca: Świattość wieczna z 1918 roku) jako ostatnią w myśli rosyjskiej próbę wprowadzenia do systemu nauki chrześcijańskiej Plotyńskiej Duszy świata, co — rzecz jasna — rodziło komplikacje zarówno natury systemowej, jak doktrynalnej. Badacz wnikliwie przedstawia meandry nauki Bułgakowa i jego stopniowe odchodzenie od neoplatońskiego pojmowania Sofii-Duszy świata w kierunku pojmowania „pośrednictwa” pomiędzy Bogiem a światem bliskiego ujęciu Palamasa (jako energii „pośredniczących"). Mając zaś na uwadze - by tak rzec — nieżyciowość i spekulatywność sofiologii Bułgakowa a także religijnej myśli rosyjskiej w ogólności (I wojna światowa, rewolucja w Rosji 1917 roku itp.), odwołując się do prac S. Chorużyja, trafnie konkluduje, że „los sofiologii, w istocie, rozwiązała historia” (s. 158).

Mimo tych zastrzeżeń Leonkiewicz stara się wydobyć pozytywne elementy nauki S. Bułgakowa, odnajdując je między innymi w książce Hipostaza i hipostatyczność (s. 168), będącej odpowiedzią teologa-filozofa na zarzuty herezji, i w konkluzji stwierdza, że autor Filozofii imienia odszedł w końcu od dyskursu neoplatońskiego na rzecz patrystycznego, przy czym, trafna jest konkluzja, że ewolucja ideowa Bułgakowa przebiegała w odmienny sposób niż Floreńskiego, który w swej „filozofii kultu", podobnie jak Bułgakow, dokonał wprawdzie konwersji z filozofii na teologię, pozostał jednak przy tym ,zafascynowanym neoplatonizmem romantykiem do końca" (s. 161).

Jak celnie stwierdza uczony, neopatrystyka, która dokonała ostatecznego rozejścia się tradycji neoplatońskiej i prawosławnej, nie była jedynym nurtem krytycznym wobec rosyjskiej filozofii religijnej. Krytykę sofiologii znajdujemy na przykład u fenomenologa G. Szpeta i pisarza I. Bunina, którzy ten typ filozofowania, zwłaszcza w obliczu historycznych wydarzeń pierwszych dekad XX wieku, uważali za „oderwane od życia marzycielstwo” (s. 162). W tym sensie — jak pisze Leonkiewicz - filozofia Srebrnego Wieku się ,skończyła” wyparta w nurcie religijnym przez neopatrystykę, która już na gruncie teologicznym dokonała, jak czytamy, ,lekkiego zwrotu w kierunku arystotelesowskim" (ibidem).

Wobec konstatacji o „końcu” sofiologii (który można poczytywać za „koniec” filozofii Wszechjedności, a nawet poniekąd za „koniec” rosyjskiej filozofii religijnej jako takiej) w zamykajacym część druga pracy rozdziale czwartym zatytułowanym Co jeśli nie neoplatonizm?, badacz słusznie podkreśla paralelność nauki Arystotelesa wobec neoplatonizmu w tradycji bizantyjskiej (Jan Filipon, Jan Chryzostom, Leoncjusz z Bizancjum, a także tacy ,arystotelicy” jak Maksym Wyznawca 
czy Jan Damasceński). Zdaniem warszawskiego uczonego podążającego tutaj za B. Tatakisem arystotelizm chrześcijański był w tradycji bizantyjskiej tak trwały jak neoplatonizm chrześcijański, a Grzegorz Palamas, odchodząc od neoplatońskich metafizycznych hipostaz, w swej nauce o energiach w istocie powraca właśnie do pism Stagiryty i jego „precyzyjnego” sposobu myślenia. Analogicznych motywów zwrotu do arystotelizmu w tradycji bizantyjskiej dopatruje się uczony u takich przedstawicieli współczesnej myśli rosyjskiej jak S. Chorużyj, W. Bibichin, czy S. Awierincew. Ten ostatni stał się autorytetem i „drogowskazem dla myśli postrenessansowej" (s. 168) przede wszystkim dlatego, że jako jeden z pierwszych podjął namysł nad sposobem filozofowania we współczesnej Rosji, innym niż tradycja Platona i Plotyna (ibidem).

Jak czytamy, w związku z zakończeniem się Srebrnego Wieku zakończył się także etap dawnej relacji filozofii i teologii, w której prymat wiodła myśl neoplatońska, kierująca myślą religijną. Autor stawia w tym kontekście trafne pytanie, jak powinna współcześnie wyglądać ta relacja, a odpowiedzi za S. Chorużyjem szuka, odwołując się między innymi do szczegółowo analizowanego studium Fenomenologia i teologia (1927) M. Heideggera. I chociaż porównanie analityki egzystencjalnej autora Bycia $i$ czasu z hezychazmem wydaje się ,karkołomne”, to jednak — jak pisze Leonkiewicz — rozróżnienie Heideggera pomiędzy teologią jako nauką „pozytywną” oraz filozofią jako nauką o „Byciu”, jest dla zrozumienia synergicznej antropologii Chorużyja bardzo cenne choćby dlatego, że teologia operuje w sferze ontycznej, tymczasem, „synergia” nie jest przemianą w wymiarze ontycznym, lecz „ontologicznym".

W części trzeciej (Postrenesans rosyjski) zamykającej książkę badacz skupił się na kluczowym pytaniu o możliwość „nowego renesansu”, „innego początku” (drugoje naczało) współczesnej filozofii w Rosji, a zagadnienie to przedstawił na przykładzie dwóch myślicieli uznanych za reprezentatywnych dla formacji rosyjskiego „postrenenasu” i wyrażających zarazem dwa różne podejścia do problemu S. Chorużyja oraz W. Bibichina. Pierwszy z nich uważa, że celem filozofii religijnej była nie tylko refleksja nad religijnością rosyjską, lecz także odkrycie duchowych zasad prawosławia i wyrażenie ich w języku filozoficznym (co znalazło wyraz w poglądach filozofów religijnych Srebrnego Wieku, na przykład S. Bułgakowa), tradycji „przerwanej” wprawdzie w okresie komunizmu, lecz będącej nadal źródłem inspiracji. Drugi z kolei będąc przekonany, że w historii filozofii rosyjskiej, mimo okresu komunizmu, nie było żadnej przerwy, lecz „milczenie”, poszukuje ,innego początku", twierdząc, że filozofia Srebrnego Wieku, z jej kosmizmem, sofiologią i podobnymi metafizycznymi hipostazami, stanowi zbędny balast myśli rosyjskiej. Postuluje przeto rewizję tej tradycji i filozofowanie w takim ,źródłowym” znaczeniu, jak je pojmował Arystoteles i Heidegger.

Rekonstruując podstawy myśli Chorużyja w rozdziale drugim ostatniej części pracy (Filozofia Sergiusza Chorużyja w perspektywie teologicznej), warszawski uczony skupia wpierw swoją uwagę na mającym kluczowe znaczenie w myśli Chorużyja fenomenie „deantropologizacji człowieka”. Wedle rosyjskiego filozofa ów proces zagubienia człowieka w myśleniu europejskim rozpoczął się już w starożytności. „Rozum — pisał Arystoleles w Etyce Nikomachejskiej — bardziej niż coś 
innego jest człowiekiem" (s. 192). Chorużyj (Lampa Diogenesa, O starym i nowym) stwierdza, że paradoksalnie w filozofii europejskiej, która zaczęła się od antropologicznego hasła „poznaj samego siebie”, człowiek się zgubił, nie poznał siebie jako całości, lecz utożsamił się ze swoją „najwyższą częścią” (s. 193). Metafizyka europejska skończyła się pod tym względem „klęską” (s. 194), czego znakiem był Kartezjański dualizm i idealizm oraz Kantowski racjonalizm i idealizm. Dlatego integralny człowiek w rozumieniu Chorużyja - jak pisze Leonkiewicz — obecny był gdzie indziej — nie w europejskich koncepcjach filozoficznych, lecz na płaszczyźnie dużo realniejszej, czyli w praktykach duchowych różnych wyznań i religii (buddyzmu, taoizmu, sufizmu etc., a przede wszystkim, praktyk prawosławnego hezychazmu) i na tym „polu metafilozoficznym”, czyli w sferze „nieklasycznego” dyskursu antropologicznego rosyjski myśliciel poszukuje integralnego obrazu człowieka.

Celem nowej „metaantropologii” Chorużyja jest nie tylko wypracowanie nowej wizji człowieka, lecz także nowego dyskursu antropologicznego. W ocenie warszawskiego uczonego ów współczesny rosyjski filozof oferuje pierwszą w myśli rosyjskiej koncepcję odchodzącą od ujęcia człowieka jako podmiotu, czystego rozumu itp., czyli tak czy inaczej esencjalnego ujęcia człowieka, ku ujęciu, w którym człowiek nie tyle jest, co staje się w egzystencjalnym „otwarciu się na inny horyzont bycia”, w „otwartości” na ,Inne”.

Dobrze świadczy przy tym o postawie badawczej warszawskiego uczonego to, że dostrzega on tak mocne, jak i słabe strony antropologii Chorużego, bo i jemu nie umknął uwagi fakt, że nie raz - jak stwierdza - pojawiają się wobec koncepcji antropologicznej rosyjskiego myśliciela uprawnione zarzuty, iż mówi ona o ,wyjątkowych przypadkach a nie o zwyczajnym człowieku" (s. 212).

Mimo krytycznej postawy wobec omawianych koncepcji w ocenie warszawskiego uczonego synergiczna antropologia Chorużyja zasługuje na ocenę wysoce pozytywną, jest bowiem „projektem”, którego celem jest stworzenie „nauki nauk o człowieku". W podsumowującej ocenie warszawski badacz stwierdza, że Chorużyj wyszedł naprzeciw nowej sytuacji, przed którą stanęła filozofia współczesna, wyrażonej w pytaniu: „Kto przychodzi po podmiocie?” i w swej próbie poszukiwania odpowiedzi stanął na jednym poziomie z najwybitniejszymi zachodnimi filozofami „nieklasycznymi” S. Kierkegaardem, F. Nietzschem, M. Heideggerem, M. Foucaultem, G. Deleuze'em, J. Derridą. Zdaniem badacza wraz z antropologią synergiczną Chorużyja w filozofii rosyjskiej pojawiła się pierwsza tak poważna próba wyjścia z ,niewoli neoplatońskiej” filozofii okresu Srebrnego Wieku.

W ostatnim zamykajacym część trzecią rozdziale Włodzimierz Bibichin $i$ rosyjski postheideggeryzm badacz zajął się myślą zmarłego w 2014 roku Władimira Bibichina. „Nowy renesans” i „nowy początek”, który miałby dokonać się w myśli rosyjskiej u Bibichina, nie tyle polega na odrestaurowaniu danej tradycji (na przykład hezychazm u Chorużyja), co na zakorzenieniu w myśli fenomenologicznie otwartej na ,świat rzeczy”. Jak pisze badacz, stan „bycia przy rzeczach" to istota postawy filozoficznej Bibichina, który w tym celu stwarza swój własny język i swoje naczelne koncepcje poznawcze, wokół których zorganizowana jest cała jego „postheideggerowska” filozofia. Stanowi je pięć zasadniczych kategorii: „Świat”, „Obecność”, „Wydarzenie”, „Własność” i „Energia” (s. 224). Im też kolejno poświęca swoje analizy warszawski badacz. 
Bibichinowską pryncypialność w podejściu do filozofii (podrozdział Srogość filozofii) Leonkiewicz trafnie ujął w kontekście zawsze aktualnego w filozofii rosyjskiej sporu pomiędzy pojmowaniem filozofii jako ,nauki” i ,filozofowania” ( $f$ Łosofstowanije, ljubomudrije). Wymóg filozofii jako powrotu do źródeł głoszony przez Bibichina temu postulatowi zdaje się wychodzić naprzeciw, ponieważ celem filozofii zawsze jest renesans, odrodzenie tego, co wieczne, a nie nawiązywanie do danej historycznej myśli. W tym też duchu badacz analizuje kluczowe kategorie myśli Bibichina, z których największe znaczenie wydaje się mieć palamistyczna kategoria „energii” i spór wokół jej pojmowania. W sporze tym — jak czytamy — autor Nowego poczatku opowiedział się po stronie oponentów Palamasa i w tym sensie rzeczywiście dzieło Bibichina można odczytywać jako próbę dokończenia sporu pomiędzy chrześcijańskim neoplatonizmem a monastyczną teologią ortodoksyjną o ,istotę i energię". Bibichin traktuje „energię" inaczej od „rosyjskiego Diogenesa" (Chorużyj), inspirując się nie Palamasową teologią energii, lecz myślą Arystotelesa. Odrzuca on tym samym kategoryczny podział Palamasa w Bogu na boską niepoznawaną istotę i poznawalne energie Boga i zalicza siebie do tradycji antypalamickiej.

W konkluzji warszawski badacz, porównując te, tak podobne a zarazem różne, filozoficzne koncepcje, stwierdza, że głoszony przez Bibichina „nowy renesans” miał wydarzyć się w Rosji, jak niegdyś renesans włoski w Italii, miał obudzić sumienie, przywrócić starożytność, „pochwycić rosyjski świat”.

Czy tak się jednak stało? Chociaż autor nie udzielił wprost odpowiedzi na to pytanie, niewątpliwie na przykładzie poglądów Bibichina i Chorużyja pokazał ścieranie się dwu określających tożsamość myśli rosyjskiej paradygmatów - neoplatońskiego oraz arystotelesowskiego, symbolicznego oraz realnego, jako nie tylko epizod z duchowej i intelektualnej historii Rosji, ale wręcz walkę o odzyskanie realnego świata dla Rosji, dla filozofii i kultury rosyjskiej „tu i teraz”. Pokazał zarazem, że droga została wyznaczona przez obie te filozoficzne osobowości, a postawione pytania zobowiązują następnych myślicieli do odpowiedzi na nie. 